\title{
For Want of a Better Estimate, Let's Call It the Year 2000: The Twilight Zone and the Aural Conception of a Dystopian Future
}

\author{
REBA A. WISSNER
}

\begin{abstract}
This paper examines the aural conceptions of futuristic dystopias in episodes of The Twilight Zone, focusing on one specific episode, season five's "Number Twelve Looks Just Like You." I examine how the music director of CBS conceived of the future, aurally representing these episodes as having an affinity with the premise of Brave New World by reusing its radio score by Bernard Herrmann. As a result, I will explore the use of the radio score in the episode and the ways in which dystopian futures were aurally represented in the series.
\end{abstract}

At the opening of the 1964 Twilight Zone episode "Number Twelve Looks Just Like You," Rod Serling sets the stage in his opening monologue:

Given the chance, what young girl wouldn't happily exchange a plain face for a lovely one? What girl could refuse the opportunity to be beautiful? For want of a better estimate, let's call it the year 2000 . At any rate, imagine a time in the future where science has developed a means of giving everyone the face and body he dreams of. It may not happen tomorrow, but it happens now ... in the Twilight Zone. ${ }^{1}$

While this seems like an ideal scenarioa utopian society-what results is everything but utopian. Nonutopian societies that create the worst possible scenarios are identified as dystopian. Dystopian societies, defined by Rudolf B. Schmerl as "the deliberate presentation of improbabilities through any one of four methods-the use of unverifiable time, place, characters, or devices - to a typical reader within a culture whose level of sophistication will enable that reader to recognize the improbabilities," generally fall within the context of fantasy. ${ }^{2}$ Works of speculative fiction also present dystopias: cautionary tales about the future's possibilities based upon elements of the present society. Whether utopian or dystopian, technological progress lies at the heart of these societies.

Science-fiction works often feature utopias and dystopias. Such narratives provide "a 'distant mirror' in which one can examine and discuss modern problems." ${ }^{3}$ The core of the dystopian genre constitutes the dichotomy between free will and coercion, and especially that of conformity. ${ }^{4} \mathrm{On}$ the one hand, the genre's narrative climax forms when there is a confrontation with power. ${ }^{5}$ On the other hand, ironically, "while it deals largely with complexity and modernity, the simple casual binaries that tend to drive its narratives_-subject/power, free will/ coercion, truth/lies-betray its primitive narrative infrastructure." 6 Indeed, Aldous Huxley's Brave New World and The Twilight Zone's "Number Twelve Looks Just Like You" fit into the paradigms of fantasy, speculative fiction, and dystopia. 
Although Huxley's novel has received much attention, studies of the radio-play adaptation as well as the various television shows that it has influenced have been neglected. This essay remedies this dearth of literature by examining the aural conceptions of futuristic dystopias in the score of the radio play for Brave New World and one specific episode of The Twilight Zone, "Number Twelve Looks Just Like You." This study examines first the similarities and differences between Huxley's novel, the short story "The Beautiful People" by Charles Beaumont, and the two teleplay versions of "Number Twelve Looks Just Like You," based on Beaumont's story. It examines the inner workings of the CBS Stock Music Library and its music directors and then studies the degree to which the music for The Twilight Zone version, reused from the Brave New World radio play, appropriately serves to aurally depict a dystopian future. ${ }^{7}$ This study will then focus on the ways in which the music director of CBS conceived of the future; he aurally represented these episodes as having an affinity with the premise of Brave New World by reusing its radio score in the televised episode. By considering the practices of one of the living Twilight Zone composers and music directors for the show, Robert Drasnin, a clearer picture of the assembly process of stock scores will emerge. This episode and the use of the radio score both serve as a case study of the ways that science-fiction television of the 1960s, specifically The Twilight Zone, aurally represented dystopian futures.

\section{Aldous Huxley's Brave New World}

Aldous Huxley wrote and published Brave New World in 1932, about a dystopian society based on eugenics. It was set in the future in London in 632 A.F. ("After Ford") or our year 2540. ${ }^{8}$ Huxley himself, however, called it a "negative utopia." William Froug adapted Huxley's story into a two-part radio play airing on consecutive weeks, and Huxley narrated the two parts for the CBS Radio Workshop, an experimental radio anthology program that ran from 1956 until 1957. Directed by Froug, the two parts formed the show's premiere, airing on January 27 and February 3, 1956, respectively. ${ }^{10}$ In the preface to his radio-play version, Huxley ominously stated, "If I were writing today, I would date my story not 600 years into the future, but at the most 200."11 He reiterated this sentiment in his Brave New World Revisited (1958). ${ }^{12}$ As a result of contemporary events, especially the mechanization of society, Huxley saw the potential for this kind of society sooner than he had originally anticipated. As Peter Firchow sees it, Huxley's novel "has become a kind of byword for a society in which the values (or nonvalues) of scientific technology are dominant, and which has therefore reduced man to a species of machine."13 This mechanization of humanity not only pervades Huxley's novel but also the radio play.

Literary scholars sometimes have described Brave New World as an anti-utopia rather than a dystopia. ${ }^{14}$ Not coincidentally, Huxley wrote the novel in response to both the eugenics movement and the depression in England. ${ }^{15}$ At the point at which Huxley wrote Brave New World, "eugenics was not a nightmare prospect but rather the best hope for designing a better world if used in the right ways by the right people."16 The basic premise of Brave New World was biological determinist: that a peaceful World State, limited to a population capacity of two billion people, thus making all goods and resources perpetually abundant, had eliminated natural reproduction and implemented births through the use of hatcheries and conditioning centers. In these places, fetuses were selected as a member of one of five castes, further subdivided into pluses and minuses of each. Fetuses chosen as members of the highest caste, "Alpha," were allowed to develop naturally while maturing to term in 
decanting bottles. However, fetuses chosen as members of the four lower castes- "Beta," "Gamma," "Delta," and "Epsilon"-were subjected to chemical interference to halt intelligence or physical growth during development.

While each "Alpha" or "Beta" is the product of one unique fertilized egg developing into one fetus, members of lower castes are created using a fictional cloning process called the Bokanovsky Process, enabling a single egg to spawn up to ninety-six children at a time so that one ovary can produce thousands of children. To further increase the birthrate of Gammas, Deltas, and Epsilons, the use of Podsnap's Technique-which speeds up the Bokanovsky Process-augments the process. People of these five castes and their subdivisions make up the majority of human society; by producing these specialized children who, by virtue of their creation are limited in their cognitive and physical abilities, society makes them easier to control since they are manufactured for their own single purpose based on their caste. To further their education for their specific purposes, they are educated via the hypnopaedic process - a kind of sleep-teachingthat provides each child with subconscious, caste-appropriate messages based upon their predetermined purpose. This conditioning serves to make people "learn to like their inescapable social destiny" and includes aversion therapy for the items to which members of each caste should not be drawn, such as cold weather, books, and flowers. People in this world age all at once-they physically turn seventeen and then remain that way until their death. Froug maintains most of the original story in the radio-play version, but the pacing of the action moves quickly due to the time constraints of a half-hour per part.

The story focuses on several characters: Bernard Marx, an Alpha-Plus psychologist and social outcast and an expert in sleepteaching who is hesitant to conform to society, and Lenina Crowne, a Beta-Minus hatchery worker whom he loves. Bernard's only friend is Helmoltz Watson, an AlphaPlus lecturer at the College of Emotional Engineering. Bernard, who is threatened with exile to Iceland, and Lenina travel to the Savage Reservation called Malpais (literally "bad country") in New Mexico. In fact, they refer to their own world as a civilization and what is essentially a nonconformist ghetto in New Mexico where the people have remained viviparous as on a savage reservation. There they encounter Linda and John and find out that Linda also came from civilization but got lost while on a trip there many years prior with the Director of Hatcheries and Conditioning, Thomas. Linda reveals that John, whom she gave birth to naturally, is Thomas's illegitimate son. Linda wants to return to the New World State as she misses civilization and the privilege of taking the narcotic, Soma. Once they all return, Bernard avoids exile by publically revealing John's lineage, and Thomas resigns in humiliation. John, who loves Lenina and wants to marry her in the way they do on the Savage Reservation, suddenly receives word that his mother is dying.

John travels to the hospital where he sees that his mother has succumbed to Soma while children undergoing death conditioning look on. Enraged at his mother's death, John causes a riot during Soma distribution. Due to their subversive behavior, Bernard and Helmoltz, unable to escape exile, are sent away. At the end, John, wanting ultimate solitude, hangs himself. The issue of social inequality brought up in Brave New World figures prominently in both Beaumont's story and Tomerlin's teleplay. In all three cases, the social inequality stems from human nature; such conflict lies at the center of dystopian societies. 


\section{The Beautiful People and "Number Twelve Looks Just Like You"}

As exemplified by Brave New World, the society that appears as dystopian is meant to be utopian to those who live in it. Yet another story that deals with such a society is Charles Beaumont's The Beautiful People and the Twilight Zone episode that it inspired, "Number Twelve Looks Just Like You." Although not eugenics per se, the Transformation that we find in both The Beautiful People and "Number Twelve Looks Just Like You" does require the scientific manipulation of humanity. In "Number Twelve Looks Just Like You," the alteration of bodies to conform to specific types bears a similarity to that in Brave New World. Like Huxley's novel, the short story and the teleplay explore both dystopian polemics and the homogeneity of humanity.

"Number Twelve Looks Just Like You" premiered in Twilight Zone's fifth and final season. The teleplay was written by John Tomerlin, premiered on January 24, 1964, and was an adaptation of Charles Beaumont's short story "The Beautiful People," which was written in 1952 and published in the September 1952 issue of Worlds of If Science Fiction. Brave New World demonstrated intellectuals' interest in the eugenics movement in that they "were drawn to [it] as a progressive, technocratic means of improving the health and fitness of populations," and "Number Twelve Looks Just Like You" does as well. Tomerlin wrote the first version of the script directly from Beaumont's story in a matter of three days. ${ }^{17}$ The series' story editor (and not Tomerlin) likely gave the episode its title. ${ }^{18}$ The screen credit bears both names. ${ }^{19}$ Although Beaumont is not credited with writing the teleplay, he did so with Tomerlin's assistance. ${ }^{20}$ There is a practical reason why Beaumont did not solely adapt the teleplay himself; by 1963, he suffered from a rapid aging disease and dementia to which he succumbed in 1967 at the age of 38-John Tomerlin or Jerry Sohl ghostwrote any episodes credited to Beaumont that were written after the fourth season.

While Beaumont never remarked on the inspiration for his story, we do know that Brave New World was widely read in the 1950 and could have served as one of his influences. Indeed, Beaumont wrote his short story before the radio-play version of Brave New World aired. Harold Lee Prosser pointed out that Beaumont's story served as a warning of the potential of both body modification and Skinnerism taken to their most extreme. ${ }^{21}$ The episode played upon the idea of physical ideals to make its point. It used famous model Suzy Parker to play Marilyn's mother Lana (and other characters), actor Richard Long and actress Pam Austin, having them represent the vision of beauty that Marilyn (played by Collin Wilcox) rejected. By so doing, this episode confronted viewers with a bold commentary about contemporary feminist politics. ${ }^{22}$ Indeed, the episode "was a powerful and haunting episode that derailed society's obsession with appearance, particularly as it pertained to women who had historically been pressured to fulfill the standards of conventional beauty." ${ }^{23}$ Both the short story and the teleplay dealt with prominent contemporary issues: technological anxiety, totalitarianism and authoritarianism, social inequality, human nature, youth culture and radicalism. As a result, these things provided the impetus for the dystopian scenarios portrayed in both the story and the episode. Tomerlin's script tended more toward morality than dramatic themes, however. ${ }^{24}$

In the teleplay, the protagonist Marilyn, about to turn nineteen years old, has received notice about her "Transformation," a physical and mental alteration process to conform to society, thereby eliminating ugliness and hatred. Before undergoing 
Transformation, she must choose one of the state's models for her new body, or patterns, in which she will reside for the rest of her life. Indeed, since only several models exist with so many people, each transformed person must wear his or her name on their suit so that others can tell them apart. Marilyn protests, saying that this would take away her identity and individuality. As in Brave New World, nothing in this new society is sacred anymore; as her best friend Valerie says, her mother married eleven times. Valerie exhibits this lack of sentiment when she tells Marilyn that she does not understand why she is so concerned about what her father said because he has died; Valerie herself says that she has always liked her own stepfathers better than her biological father. ${ }^{25}$ This bears a similarity to Brave New World in that one of the bits of conversation recounted in the hatchery indicates that "everyone belongs to everyone else"; the idea of having a monogamous relationship seems appalling.

Marilyn's mother, Lana, alarmed that Marilyn does not want the Transformation, takes her to a doctor, Dr. Rex, to find the underlying cause for her reasoning. Dr. Rex tells Marilyn that the doctors will not force her to undergo Transformation, but rather they intend to figure out why she does not want it and then make the necessary corrections. Dr. Rex, after finding through a series of tests that Marilyn is of sound mind and high intelligence, refers her to a psychiatrist, Professor Sigmund Friend (an obvious play on Sigmund Freud), who refers to himself as Professor Sig. According to him, "wiser men" than he established Transformation in order to eliminate injustice and inequality in the world since they figured out that "physical unattractiveness was one of the factors that made men hate." Professor Sig tells Marilyn that people can now live longer, reduce the signs of aging and decay, and avoid illness and disease, just by undergoing Transformation. ${ }^{26}$
We learn from Marilyn's conversation with both Professor Sig and Valerie that her father-who introduced her to banned books by authors such as Shakespeare, Socrates, and Dostoyevsky that talk about beauty, individuality, and love-committed suicide after undergoing Transformation. He felt that Transformation destroyed his individuality and as such he felt that he had no reason to continue living. When Marilyn brings the discussion of her reading these banned books into the conversation with Professor Sig, he responds by saying, "the introduction of smut into this interview will not help your case, young lady," admitting her into the hospital. When we see Marilyn in the hospital bed, she tells her mother and Valerie that they will make her have the Transformation anyway. As her mother reminds her that Dr. Rex promised he would not, we already see that Marilyn wears a tag indicating pattern number 8 attached to her gown; even the body that she will live in forever has been chosen for her. ${ }^{27}$ At the end, Marilyn does undergo the procedure and not only wears one of the society's bodies but also has one of their perpetually happy personalities. She emerges as Number 8 and now looks exactly like her best friend, which, she says, is "the nicest part of all." 28

The shooting script of the teleplay differs from Beaumont's original in several ways. First, two versions of the teleplay exist. The first is the closest to Beaumont's story, even keeping the characters' names. The second is the revised shooting script for the final version of the episode. In the first version of the teleplay, the personality is built to suit the body, and as soon as the person receives a new body, a new conformist personality emerges. In Beaumont's story, Mary becomes virtually blacklisted: she loses her job, and no one wants to be around her or her mother because of her "ugliness" and her refusal to undergo Transformation. In the original script and Beaumont's story, Val is a male, likely Mary's boyfriend. 
While Tomerlin maintained the Cuberle surname and Val's name in the revised shooting script, he changed all other names including the first names of Lana, Marilyn, and Dr. Friend (Zena, Mary, and Dr. Hortel, respectively). The short story began in the waiting room of the doctor's office, eliminating the opening scene in the living room of the teleplay. The original version of the teleplay also included a second psychiatrist named Dr. Mann. The original shooting script referred to the nurses as automatons. In Beaumont's story, books were not banned, but rather people stopped using them when tapes came into existence, similar to the recorded books of Brave New World. In the teleplay, however, books have been banned. Both the Brave New World radio play and the "Number Twelve Looks Just Like You" teleplay refer to Shakespeare as smut. In Brave New World, the New World State prohibited the writings of Shakespeare for their subversiveness. Incidentally, however, the title of Huxley's novel is derived from a line in The Tempest. Tomerlin maintained verbatim from the short story much of Dr. Rex's speech to Lana and his interpretation that Marilyn was just impatient about undergoing the Transformation. However, Tomerlin kept much of the dialogue in the first version of the teleplay for the final shooting script, originally titled after the short story, "The Beautiful People," a title to which Serling referred in his original monologue:

What girl does not want to be beautiful? Given the chance, what girl would not be happy to exchange a plain face for a lovely one? Imagine a time when science has developed the means of giving everyone the face and body he dreams of. And imagine-if you can - a girl who has decided that she does not want to be one of-The Beautiful People. ${ }^{29}$

Tomerlin even altered the final version of the monologue from the one in the shooting script to reflect the new title of the series:

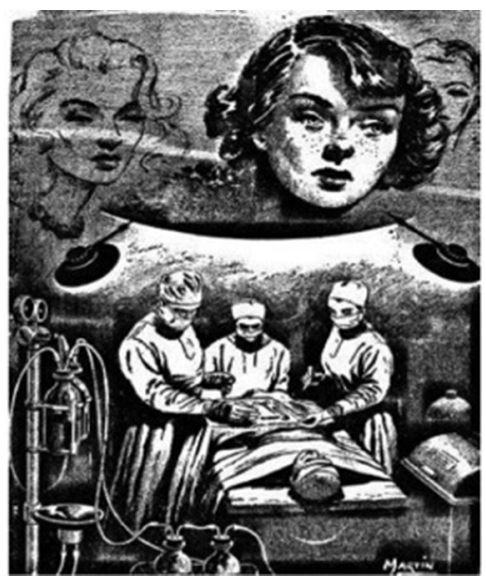

Plate 1: Illustration from "The Beautiful People" in Worlds of If Science Fiction (September 1952)

\begin{abstract}
What young girl would not [want] to be beautiful? Given the chance, what girl would not be happy to exchange a pretty face for a lovely one? Imagine a time in the not too distant future when science has developed the means of giving everyone the face and body he dreams of. It can happen tomorrow. It happens now ... in The Twilight Zone. ${ }^{30}$
\end{abstract}

Plate 1 reproduces an illustration from the short-story publication featuring the Transformation process. In the teleplay, Transformation is implied and seems simple, as Plate 1 shows: the doctors put the patient under a giant glass where they are altered almost instantaneously. The short story version is more graphic, as Mary's mother says,

It doesn't hurt. They just take off a little skin and put some on and give you pills and electronic treatments and things like that. It doesn't take more than a week. . . . If it's the bones you're worried about, well, that doesn't hurt. They give you a shot and when you wake up, everything's molded right. Everything, to suit the personality. ${ }^{31}$

There are some fundamental similarities between Brave New World and "Number 
Twelve Looks Just Like You." Although no distinct caste system presents itself in "Number Twelve Looks Just Like You" and Brave New World, both allude to a class structure. In the former when Lana's maid calls her Mrs. Cuberle, Lana replies, "I don't know why teaching you people to use first names is such a problem." ${ }^{32}$ In this way, Lana does not refer to her maid as an equal, but rather a subordinate, almost implying that she is manufactured as a maid rather than choosing that as her vocation. ${ }^{33}$ This too bears an affinity to Brave New World in the mass production of people specifically for the vocational positions they will hold. In fact, in Beaumont's short-story version, Transformation takes place not in a hospital as in the teleplay version, but in a "factory."

While in the teleplay version, Marilyn is somehow placated to and accepts the idea of the Transformation; in the short story, a two-thousand-signature petition mandates it. As the story implies, Transformation is nothing more than advanced plastic surgery: "Oh yes, there's a great deal to be salvaged; you'd be surprised. A great deal. We'll keep the nose and I don't believe the elbows will have to be altered at all." ${ }^{4}$ Unlike the teleplay, the short story ends inconclusively with Mary lying on a table in the Transformation room with a "big machine" descending upon her-visible in Plate 1 -as she asks the poignant question, "Where will I find me when it's all over?"35 This was a direct reference to a line in the Brave New World radio play in which Bernard asks Lenina, "Don't you ever want to just be you? Not enslaved by conditioning?" Lenina's reaction is that everyone is happy and that Bernard should just take Soma, a pleasure narcotic, to get rid of his negative thoughts. Similarly, Marilyn's uncle and mother suggest that she drink a cup of Instant Smile to be happy like everyone else. Because Tomerlin's teleplay refers to improvements in the Transformation process from "past methods," we may assume that

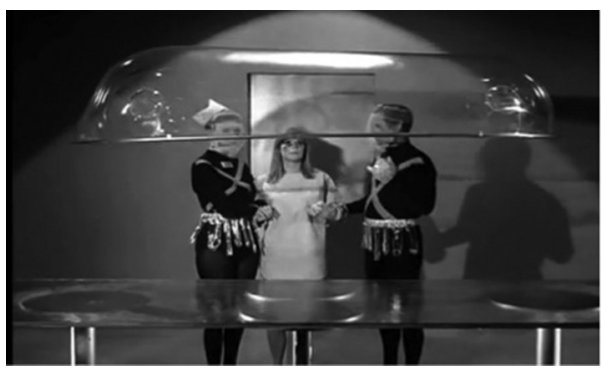

Plate 2: The Transformation in "Number Twelve Looks Just Like You" (Image Entertainment)

Beaumont's short story represents these outdated methods to which the teleplay refers.

\section{Bernard Herrmann, the Brave New World Radio Play, and "Number Twelve Looks Just Like You"}

A brief word should be said regarding musical semantics. As David Cooper has cogently argued, "meaning, in however constrained and limited a sense [that] this is understood, can become attached to music; and that music is able to interact with other elements of the narrative to form compound signifying tokens." 36 In the case of dystopian music, it is evocative of several of Cooper's categories of musical codes: context-driven associations, or "codes that result arbitrarily from the audiovisual situations"; isomorphisms, or "iconic codes that involve identities between musical shapes and extramusical events"; and intertextuality, or "codes that depend in the invocation of other styles or works." 37

Bernard Herrmann intended for the music of the Brave New World radio play to depict a dystopian world. In this sense, its reuse in "Number Twelve Looks Just Like You" was particularly appropriate. Not much attention has been given to what constituted music that depicted dystopias, especially in film. ${ }^{38}$ William Lawrence McGinney, however, wrote about dystopian music in sciencefiction films of the late 1960 s to late 1970 . He intimated that several conditions would 
create appropriate music for dystopian environments in films:

\begin{abstract}
"Dystopian" conditions are indicated as such by music incorporating distinctly modernist sounds and techniques reminiscent of twentieth-century concert works that abandon the common practice. The accompanying music feature[s] nonfunctional harmony, atonality, a focus on timbre over pitch strikingly unusual instrumentation, or other sonic traits encountered in music of the twentiethcentury that are often considered to render such music difficult or inaccessible to mainstream audiences. ${ }^{39}$
\end{abstract}

Such music, as McGinney described it, was often considered "difficult" or "alienating" and as such, represented a dystopian element in films. ${ }^{40}$ As we will soon see, there were several bitonal and atonal moments in Herrmann's score. Electronic sounds “developed associations with machines, mechanization, and artificiality that [had] been alternately championed and disparaged." 41 Thus, "modernist musical styles [accompanied and characterized] those dystopian conditions, conferring on them the alienating and unpalatable effects that had come to be associated with that music." ${ }^{42}$ While Herrmann did not use all of these elements in the radio score for Brave New World, we must acknowledge the significance of the moments where at they sound.

At the same time that Herrmann composed the score for the Brave New World radio play, he was also writing the music for the films The Man Who Knew Too Much and The Wrong Man. Not surprisingly, Herrmann conceived of the radio-episode's score specifically as radio music that, in general:

serves essentially to create atmosphere and heighten emotion. It keeps the story moving by giving it color and by holding the attention of the listener. It has the added, special function peculiar to the medium because it must attempt, together with the narrator and sound effects, to compensate for the missing visual image. ${ }^{43}$

The music of the Brave New World radio play consisted of three types: bridges, or short segments of music typically lasting ten seconds or less that conveyed a transition in time or locale; background music, or music that lent the scene a mood or accompanied dialogue and/or action; and curtains, or pieces that indicated the end of an act or scene.

The radio broadcast was received with great acclaim in Variety where an article about it mentioned the way its unique music emphasized the scenes to a greater extent than sets or costumes ever could:

Old-timers will hail the return of composer-conductor Bernard Herrmann, once altar boy to Monsignor Norman Corwin and an old radio and Workshop hand. His contribution underscores the score's importance in radio-and music's relatively neglected status in video. It would not be far-fetched to argue that special music, written to supplement and implement story needs, often is better (and cheaper) than scenery. ${ }^{44}$

Other than acknowledging the musical score in Variety, an article in the February 6, 1956 issue of Time noted its unique approach to sound design and its contribution to allowing the listener to imagine this New World State in the radio play's first part:

It took three radio sound men, a controlroom engineer and five hours of hard work to create the sound that was heard for less than thirty seconds on the air. The sound consisted of a ticking metronome, tom-tom beats, bubbling water, air hose, cow moo, boing! (two types), oscillator, dripping water (two types), and three kinds of wine glasses clicking against each other. Judiciously blended and recorded on tape, the effect was still not quite right. 
Then the tape was played backward with a little echo added. That did it. The sound depicted the manufacturing of babies in the radio version of Aldous Huxley's Brave New World. ${ }^{45}$

While not indicated in the score, the studio planned this sound using musical instruments and other objects. These items created a sound evocative of a futuristic factory where people-not machines-are manufactured.

Bernard Herrmann scored Brave New World for harp, celesta, Hammond organ, and a variety of percussion instruments: timpani, bells, rattle gourd, vibraphone, Chinese temple blocks, snare drum, and a suspended cymbal played with a wire brush. With the exception of the percussion, the cues' instrumentation is not contingent upon their function. As Steven C. Smith has remarked, "Herrmann's score was typically (and necessarily) minimal, written for six percussionists and centering on a ticking hypnotic ostinato for xylophone and organ that mirrored the childlike placidity of life in the twenty-third century." ${ }^{46}$ Aside from his choice of instruments in keeping with his tendency toward unusual orchestrations and instrumental combinations, his choice for this ensemble was pragmatic, bound by budgetary constraints; as such, most of Herrmann's radio scores only used a handful of instruments. ${ }^{47}$

Aside from affirming dystopian elements in a television score, the ways in which Herrmann used and manipulated his musical practices demonstrated the ways in which he conceived of music that depicted various environments, events, or associations. With few exceptions, Herrmann favored short melodic cells-typically no longer than two barsthat he composed and repeated in different variations and orchestrations throughout his radio, film, and television scores. A small number of his cues lasted longer than thirty seconds and often comprised no more than a few notes. ${ }^{48}$ This conformed to his antitune tendency and also gave way to his practice of isolating specific harmonic colors depending on the situation. ${ }^{49}$ Although he had an undoubted tendency toward construction using two-measure units, Herrmann did not invariably restrict himself to eight-measure phrases in his scores.

Herrmann also avoided extended melody. In its place he used small groups of notes that often lasted only two measures. ${ }^{50}$ This practice still resulted in eight-measure phrases comprised of four two-bar increments, often constructed on a rhythmic or melodic ostinato. Because of the way in which Herrmann crafted his two-measure phrases, the resulting eight-bar phrases were almost never melodic. ${ }^{51}$ Herrmann often employed ostinatos in his radio, film, and television scores during scenes that required a buildup of tension but lacked dialogue. ${ }^{52}$ Herrmann also used ostinatos in his music to accompany or depict obsessive behavior. ${ }^{53}$ As Mark Russell and James Young noted, in reference to Herrmann's scores for Alfred Hitchcock (and this particularly held true for his other scores as well), "ostinato figurations stubbornly refuse to transform themselves into conventional melodies: instead, the fragmentary repeating patterns are formed into kaleidoscopic musical textures that tread a precarious middle ground between stability and instability." ${ }^{34}$ Likewise, Kristopher Spencer observed that the pervasive use of ostinatos with inconclusive harmonies altered the audience's expectations while simultaneously rarely providing any melodic reassurance. ${ }^{55}$ This juxtaposition of instability and stability with a refusal to resolve formed aural hallmarks of dystopia: an unstable world filled with tension without the comforts of release. Some of Herrmann's ostinatos outlined a specific chord meant to not resolve (see below).

Within the context of Brave New World and "Number Twelve Looks Just Like You," Herrmann's trademark short melodic cells 
and incessant ostinatos were crucial for his portrayal of a dystopian world, making the score adequate for both shows. Since the radio play premiered in two parts, Herrmann composed the score in two parts as well. Herrmann numbered rather than named his cues here, according to his typical practice. The cues themselves were rather short and some of them, such as Part 1, Cues 1, 6, and 12 recurred throughout both parts. There is no Cue 2 in Part 1 of the score for the radio play, rather the music of Cue 6 replaced it. Further, Part 1, Cue 1 was the same as Part 1, Cue 13. The cue for Part 2, Cue 7 was never used in the radio play. Each cue was a half page to a single page in length, and most contained repeats. Nonetheless, the brevity of each cue highlighted the moment that it accompanied. The repetitiveness of each of the cues helped mimic the conformist plot. Some cues among the two parts of the radio show, however, bore some similarities.

Music in this radio play functioned as categorized by Boris Kremenliev, as signature, curtain, bridge, and background. ${ }^{56}$ The cues predominantly transitioned between scenes and worked also as background underscore. In "Number Twelve Looks Just Like You," the cues functioned in a similar manner. Most of the Brave New World cues reused in "Number Twelve Looks Just Like You" were placed in moments of underscore; only in a hand-

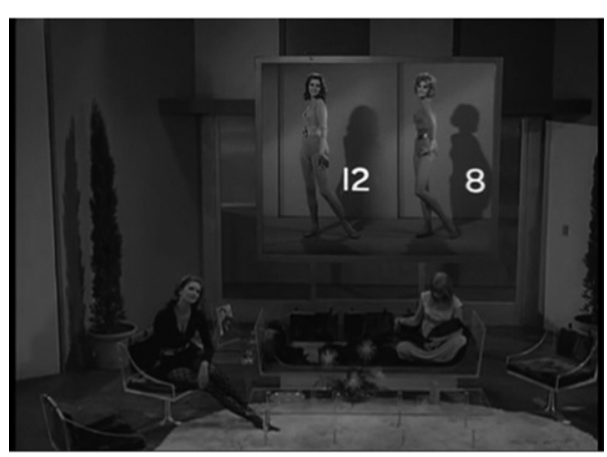

Plate 3: Opening scene of "Number Twelve Looks Just Like You” (Image Entertainment) ful of instances did they function as scenic transitions. For example, the same cue used in the hatchery in the radio play is used in the opening scene of "Number Twelve Looks Just Like You" as Lana remarks that she cannot decide whether she prefers numbers 8 or 12 for her daughter, as shown in Plate 3.

The reuse of previously composed cues in television shows produced by the CBS network began in 1956, with the establishment of the CBS Television Music Library, so that the network could reuse music from previously aired television and radio shows in new shows to cut down on the cost for composing and recording new scores. In order to do this, every score composed by a musician on the CBS payroll was recorded and placed in the Library, often recorded several times with various tempos and endings so that the cue would provide a large variety of music for a plethora of situations so that they could reuse them virtually anywhere. ${ }^{57}$ This pervasive reuse of stock music resulted in a labor strike by CBS musicians in 1957, resulting in a mandatory dictum that any television series running a complete season of 39 episodes must use a minimum of 13 original scores to keep the recording studio musicians employed, and the remaining 26 or less could use music from the CBS Library. ${ }^{58}$

Before assigning a composer to write a score for an episode, supervising music editor Eugene Feldman and assistant music supervisor Lud Gluskin would watch the rough cut to gauge the appropriateness of any library music. If they felt existing cues from the Library would make for a good fit, they would choose those cues and dub the recordings in the appropriate place. ${ }^{59}$ Once recorded, the network would then have the right—as the composer's contract would stipulate-to reuse the music where the music editor or music director saw fit. If they felt that it did not merit an original score, he or an appointed music editor or director would find appropriate music from the CBS 
stock holdings and decide on the placement of each cue. ${ }^{60}$ As such, the rise of the recorded network library indicated a reallocation of responsibility away from the composer and toward music and sound editors and music directors in which the latter became the creators of an episode's soundtrack by selecting appropriate prerecorded musical excerpts.

The reuse of cues generally depended on the onscreen action. Twilight Zone composer Robert Drasnin, who also worked as music director for the CBS Library throughout The Twilight Zone's run, remarked in personal correspondence on his experience of working to create an episode score from existing music:

\section{Creating scores from The Library was both a challenge and a source of frustra- tion. Trying to make a coherent, unified score with music from different compos- ers with different orchestration wasn't easy. Fortunately, there was music by Jerry Goldsmith and Bernard Herrmann avail- able. $^{61}$}

As evident from the plethora of episode scores compiled from Library cues, the music directors relied heavily upon Herrmann's cues for radio and other television series. In fact, of the 156 episodes of The Twilight Zone, 57 used either original scores or at least one piece of stock music by Herrmann. As the cue sheet in Plate 6 shows, both Herrmann and Goldsmith's cues appear in "Number Twelve Looks Just Like You."

While Drasnin did not compile the stock score for "Number Twelve Looks Just Like You," he has given some insight as to the manner in which the cues for stock scores were typically compiled. As Drasnin recounted, for him, creating a new score and one from Library music warranted the same basic procedure. Once they spotted the episode, he then waited for Gluskin or Feldman to give him detailed timing notes in which they broke down these events chronologically in minutes and seconds, giving him a frame of reference from which to work. $\mathrm{He}$ considered the appropriate musical idiom for the episode as well as tempo and places that might require a musical inflection such as a change of scene that might necessitate a modulation, change in texture or orchestration, or dialogue or sound effects. From here, he went to the Library to check the availability and the length of these particular cues, choosing ones that he felt appropriate. ${ }^{62}$

Some of this music derived from other television series prior to The Twilight Zone, such as Gunsmoke (1955-1975), Perry Mason (1957-1966), and Have Gun-Will Travel (1957-1963), as well as music originally composed for various CBS radio dramas, such as "Brave New World." Consequently, when some of these cues were reused, their reuses occurred in moments that had a completely different context, while others were placed in the context of similar situations. CBS, as well as other studio libraries, kept a card catalogue of titles as a finding aid. Often these bore exact dates of all uses of cues so that they could easily access what episodes of what series utilized a certain cue. The music department organized the cues into reels by their general uses and categories (such as suspense, dramatic punctuations, and space fantasy), combined with timings, the name of the composer, and a short description of the cue, as well as the take number of the recording and what made it different from another recording of the same cue (such as a different ending or whether the strings or brass played the cue open or with mutes). This enabled a music director to narrow down the possible cues that he could employ in a specific dramatic situation.

The more mainstream a score, the greater the likelihood that its cues would be reused. Twilight Zone composer Leonard Rosenman noted that the music department considered original scores necessary if the episode was, 
as he described it, extraordinary. ${ }^{63}$ Similarly, Twilight Zone producer Buck Houghton noted that the CBS Music Department often found themselves using mostly music from The Library unless it was something so unique that it would not be found there. He emphasized that the CBS Music Department reused a cue if it had a particular sound to it, but on the other hand, if the episode featured a generic action such as people dancing and the network wanted to add something like background waltz music, it came from the CBS Library. ${ }^{64}$

Herrmann composed various scores for CBS radio programs, and cues from several of his scores made it into episodes of Rod Serling's Twilight Zone, such as "Number Twelve Looks Just Like You.” As part of network protocol, the score was placed in the CBS Stock Music Library for reuse in subsequent radio and television shows. As a result, many episodes of The Twilight Zone did not contain original scores but rather a bricolage of stock music culled from the CBS shelves. The score for "Number Twelve Looks Just Like You" was comprised entirely of stock cues. The use of cues in multiple episodes over multiple television series occurred relatively frequently in the 1950 s and 1960s, especially since television episodesand, to a certain extent, radio plays-tended to function as a basic blueprint of narrative with stock situations, as illustrated by their recourse to the same stock music cues at similar moments, thus revealing the extent to which dramatic situations were stock situations. Television tended to rely on commonly understood musical sounds and styles to convey a specific idea or character and, as such, musical style conventions or topics could connote anything from objects and locations, to demographics and behavior. ${ }^{65}$ Ron Rodman observed, "The music played bonds with the images and sounds of the TV program and conveys some sort of representational meaning to the program." 66
In order to achieve the desired effect for similar situations within other episodes, it was an accepted convention to reuse cues that easily conformed to given musical topics. Therefore, we can glean the main premise of the CBS Stock Music Library and other network music libraries: to relate specific types of music to generic situations in order to enable their reuse in an effort to save the network time and money.

The music for The Twilight Zone series falls into three basic categories: wholly composed of new music, possibly with a stock track or two thrown in; partial scores composed of new and stock music; and scores completely comprised of stock music. As a result, many episodes of The Twilight Zone do not contain original scores but rather a bricolage of stock music culled from the CBS shelves. This episode contains five cues from the Brave New World radio play, four from The Twilight Zone episode "A Hundred Yards Over the Rim," and one from The Twilight Zone episode "The Invaders," and a library cue from the composer Marius Constant. Sometimes an entire score would be comprised of stock cues as in the case of "Number Twelve Looks Just Like You," but sometimes a newly composed score would still have some stock cues interpolated.

Given the similarities in the plot between the Brave New World radio play and "Number Twelve Looks Just Like You," reusing the cues from the former must have seemed an obvious solution to score the latter. ${ }^{67} \mathrm{Al}$ though Herrmann's cues are in the minority in this episode, the orchestration ties all of them together. All of the cues in the episode contain harp and some sort of percussion and/or keyboard, whether a celesta, piano, Novachord, or vibraphone, tying the sound together. Only the following Brave New World cues appeared in "Number Twelve Looks Just Like You": Part 1, Cues 3, 4, and 6 and Part 2, Cues 2 and 3. These cues have some things in common, which explains 
why, out of all of the radio score's cues, they might have been chosen. All of the cues use harp, celesta, and Hammond Organ. Part 1, Cues 2, 4, and 6 use vibraphones. Additionally, their context in the Brave New World radio play can also shed some light on this, as discussed earlier.

None of Herrmann's cues for Brave New World truly resolve to any sort of tonic. The absence of this underlying tonic is rare in Herrmann's music, making its absence here particularly significant. Conformity, a hallmark of dystopia, is a topic that Herrmann tends to depict in many of his film scores and one of the only types of his music that contains the absence of an underlying tonic. In looking at Herrmann's dystopian film scores, we can see some ways that he approaches this musical depiction. In his film score for the quintessential dystopia conceived by author Ray Bradbury (and composed a decade after the Brave New World radio play), Fahrenheit 451 (1966), Herrmann uses the ostinato to depict the conformist firemen, while "chromatic music ... suggests the isolation and repressed emotions of the rest of the population." 68 The theme, at its most prominent in "The Fire Truck" cue, "consists of a steadily driven chordal idea based on a seven-beat metric pattern." ${ }^{69}$ As Laurence MacDonald notes about Herrmann's score for Fahrenheit 451, "using an orchestra of strings, harp, and metallic percussion, Herrmann accompanied this story of a bookless society with wondrous music, including the fire truck theme, which consists of a steadily driven chordal idea based on a seven-beat metric pattern." ${ }^{70} \mathrm{Her}$ rmann specifically noted that since the film's characters are "politically oppressed from displaying any emotion or compassion, I felt that the music score should mirror the innermost thoughts and feelings of the leading character." ${ }^{\text {71 }} \mathrm{He}$ reflects this in a score that contains a pervasive ostinato and cues that repress any innovative structures.

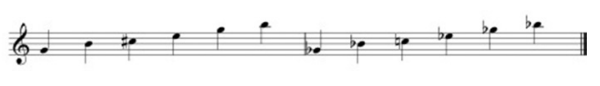

Example 1: Ostinato from "Eye of the Beholder." Bernard Herrmann, "Eye of the Beholder," CBS Collection. University of California, Los Angeles

Another of Herrmann's scores featuring conformity in the future was also for The Twilight Zone: "Eye of the Beholder" (1960). ${ }^{72}$ Here, the ostinato appears from the very first measure of the episode score and follows in every subsequent cue, thus pervading the entire episode.

Herrmann's chromatic ostinato in "Eye of the Beholder" functions in the same way as those in "Number Twelve Looks Just Like You" despite the fact that he did not compose the cues specifically for that episode. The ostinato in "Eye of the Beholder" represents the society's conformist ideals in that everyone must have a specific appearance to avoid exile to a ghetto. Chromaticism also plays an important part in Herrmann's cues for the Brave New World radio score. Much of the score features chromatic moments, sometimes to differentiate from and combine with an ostinato, as in the three-note repeated melody in the Hammond Organ in Example 2, which is Part 1, Cue 6, the cue most frequently reused in "Number Twelve Looks Just Like You."

As alluded to earlier, the chromatic ostinati here are all neighboring half-diminished seventh arpeggiations, a widely used post-Tristan gesture by Herrmann. Although often known as the Tristan Chord, William Wrobel has playfully termed it the Bernard Herrmann Chord since the composer uses it in his music with such frequency. Wrobel notes Herrmann's usage of it to connote restlessness or overall dramatic tension. ${ }^{73}$ Such a harmonic unit-one that evades its cadence and as such contains a lack of resolution-has semiotic 


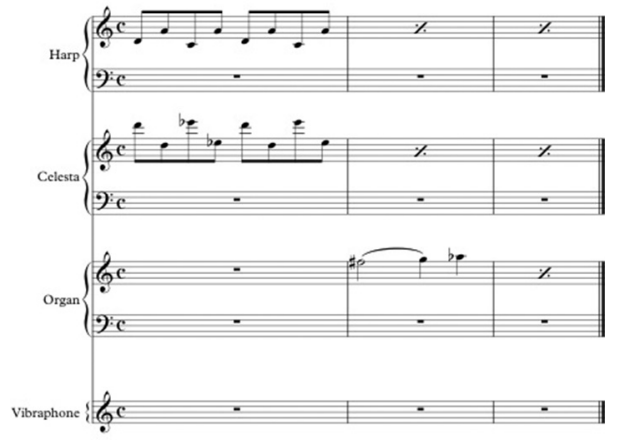

Example 2: Bernard Herrmann, Brave New World Radio Score, Part 1, Cue 6, mm.1-3

connotations of the transcendence of desire in its partial fulfillment of harmonic expectation. As such, there is more to this harmonic unit here than meets the ear. Its use in moments of conformity here not only represent a sense of uniformity but also the ceaseless oppression of the characters that would ordinarily be released through a cadential gesture, one that in these cases remain unfulfilled.

Measure 1 of both the celesta and the harp in Part 1, Cue 6 of the Brave New World radio score form the basis of one of the most prominent cells in the score and also one of the most recurring ostinatos. Here, the ostinato depicts the type of conformity found in Huxley's hatchery and is reused in "Number Twelve Looks Just Like You" at the moments that Marilyn is confronted by the prospect of undergoing Transformation. In the radio play, this cue accompanies the bottling room in which people receive their conditioning based upon their caste. In the Twilight Zone, the episode "Number Twelve Looks Just Like You" takes conformity to the extreme where everyone looks like someone else-the only variation is that of the patterns sent by the bureau. As Plate 4 shows, Marilyn (on the left) now looks just like Valerie (far right), both of whom have taken Number

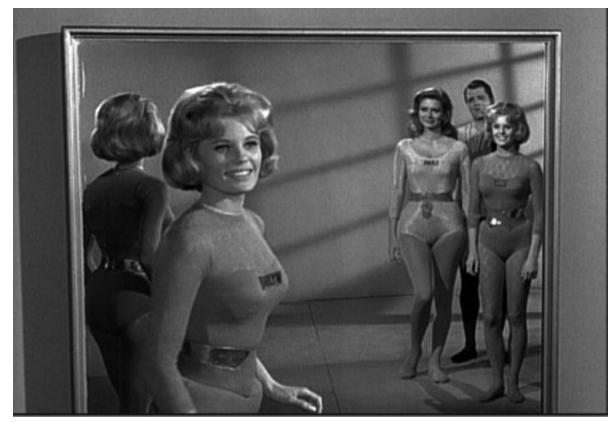

Plate 4: Marilyn, Lana, Dr. Rex, and Valerie (Image Entertainment)

8. Her mother (center), the maid, one of the nurses, and one of the surgeons are all Number 12.

All of these cues have one thing in common: the use of an ostinato-bass or otherwise-to musically depict the conformist principles of the society. Just as the repeated music contains a perceived monotony, so too does the musically depicted environment of conformity. The use of an ostinato also represents the society's focus on mechanization.

There are also affinities between the location of the cues in both the radio play and the teleplay. The first cue played in both the first part of the teleplay proper and the teleplay is Part 1 , Cue 3. This cue accompanies the scene in the radio play in which the characters enter into the hatchery. In the latter, we see Marilyn emerging from the Transformation room, looking just like Valerie; reproduced in Plate 4. In a sense, the new Marilyn has just hatched.

Part 2, Cue 2 is one of Herrmann's bitonal cues, simultaneously in D Major and C Major. The ostinato in the xylophone outlines C Major under the celestas polychords and tone clusters in D Major. The two superimposed keys represent both the instability and uncertainty of society.

Part 1, Cues 3 and 4 and Part 2, Cue 3 are the only ones used in "Number Twelve 


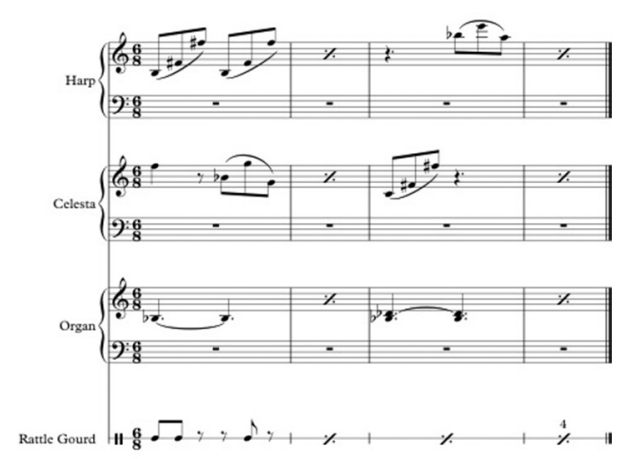

Example 3: Bernard Herrmann, Brave New World Radio Score, Part I, Cue 3, mm. 1-4

Looks Just Like You" to not have any ostinato. Rather, they use repeated melodic elements in all of the parts to drive home the listeners' expectation. As such, the repetition of the music in each part emphasizes the predictability of the situation in the same manner that the ostinato does.

\section{Conclusion}

So what exactly makes Herrmann's score for Brave New World aurally evocative of dystopia? In the case of Brave New World, the New World State is a place of conformity, one where the people and the music, carefully crafted with ostinatos, are the same. The score consists of limited melodic material and almost pervasive percussion. Although Herrmann composes his cues using some atonal moments, he tends to focus on timbre over pitch with unusual instrumental combinations and modernist musical vocabulary such as bitonality. The artificiality of the environment that the Brave New World score accompanies is emphasized with an electronic instrument-the Hammond Organ.

Radio music, unlike television music, must carefully create dramatic effect since its music "work[s] its magic through hearing alone" thanks to the lack of any visual. ${ }^{74}$ Therefore it comes as no surprise that such carefully crafted scores originally conceived for a drama without visuals could be used to great effect to enhance one with visuals. As we have seen in the case of The Twilight Zone, cues from various sources were often pieced together to form a coherent score, and sometimes these cues came from radio plays such as Brave New World. Similar to other radio plays and even television shows, the cues from Brave New World were associated with specific situations meriting their reuse. I have attempted to discuss the music of the Brave New World radio play and "Number Twelve Looks Just Like You" to illustrate the different ways that the music department at CBS reused cues, but also to bring to light the ways that other networks may have employed their music libraries.

Indeed, radio music was just as famous for its strategic underscoring as its judicious use of musical punctuation, creating unique and intriguing soundscapes. As a result, its reuses in television shows of the 1950 and 1960s, made possible by the CBS Stock Music Library and other network music production libraries, allowed for the world of the radio play and the aural image that they projected to be transferred to a whole new world on screen. That the malleability of the cues allowed for their reuses from radio to television and from one television episode to another was a testament to Bernard Herrmann's and the other CBS composers' great compositional abilities and musical imagination. The reuse of cues from CBS radio plays in The Twilight Zone formed a coherent picture of the reasons why audiences aurally associated certain music with specific events as well as contributed to an understanding of the ways in which those behind the network music libraries worked to create many scores from one.

As this essay has shown, Herrmann often used his typical techniques for composing in a multitude of ways and was still able to depict specific environments. The music that Herrmann used to represent dystopian 
environments included pervasive ostinati, chromaticism, and electronic instruments, often combined. Through this brief examination, we have seen the ways in which the score of the Brave New World radio play was appropriated for television purposes and the ways in which the cues were considered appropriate for similar circumstances on the small screen.

Since several other episodes of the series that involved similar futuristic and dystopian environments need to be explored, much remains to be done on the reuse of the Brave New World radio score in The Twilight Zone series. For now, though, a clearer picture has emerged of the ways in which the CBS Music Library and its employees operated, setting the groundwork for an understanding of the ways that stock music was employed, new scores created from existing music, and musical conventions were created.

\section{NOTES}

1. John Tomerlin, "Number Twelve Looks Just Like You," in Forgotten Gems from "The Twilight Zone”, ed. Andrew Ramage, vol. 2 (Albany, GA: Bear Manor Media, 2006), 162.

2. Rudolf B. Schmerl, "Two Future Worlds of Aldous Huxley," PMLA 77 (1962): 328.

3. Morris Emory Franklin III, "Do Not Attempt to Adjust the Picture: The Cold War Crisis of Liberal Democracy and Science Fiction Television" (PhD diss., University of Utah, 2008), 31.

4. Sean A. Witters, "Words Have to Mean Something More: Folkloric Reading in Brave New World," in Huxley's Brave New World: Essays, ed. David Garrett Izzo and Kim Kirkpatrick (Jefferson, NC: McFarland, 2008), 73.

5. Witters, "Words Have to Mean Something More," 74 .

6. Ibid., 73 .

7. For more on the use of music in The Twilight Zone, see James Wierzbicki, "Music in The Twilight Zone," in Music in Science Fiction Television: Tuned to the Future, ed. K. J. Donnelly and Philip Hayward (New York: Routledge, 2013), 1-13.

8. The era of Ford is named after Henry Ford who created the concept of the automobile assembly line, which, in Huxley's world, also applies to human reproduction in that numerous embryos are created in assembly line fashion to create many babies.

9. Aldous Huxley, introduction to part 1, Brave New World [radio play], CBS Radio Workshop, January 27, 1956, accessed March 3, 2001, http:// archive.org/details/CbsRadioWorkshop-BraveNewWorldjohnr2443.

10. Both parts of the original radio broadcast can be accessed here: http://archive.org/details/ CbsRadioWorkshop-BraveNewWorldjohnr2443.

11. Ibid., opening narration.

12. Aldous Huxley, Brave New World Revisited (New York: Harper and Brothers, 1958).

13. Peter Firchow, "Science and Conscience in Huxley's Brave New World," Contemporary Literature 16 (1975): 301.

14. Scott Peller, "Laboring for a Brave New World: Our Ford and the Epsilons," in Huxley's "Brave New World": Essays, ed. David Garrett Izzo and Kim Kirkpatrick (Jefferson, NC: McFarland, 2008), 62.

15. Joanne Woiak, "Designing a Brave New World: Eugenics, Politics, and Fiction," Public Historian 29 (2007): 105.

16. Woiak, "Designing a Brave New World," 106.

17. Tomerlin, "Number Twelve," in Ramage, Forgotten Gems from "The Twilight Zone," 160.

18. Ibid.

19. Ibid., 161.

2o. Ibid., 160 .

21. Harold Lee Prosser, Running from the Hunter: The Life and Works of Charles Beaumont (San Bernardino, CA: Borgo Press, 1996), 53.

22. Novotny Lawrence, "Reflections of a Nation's Angst; or, How I Learned to Stop Worrying and Love The Twilight Zone," in Space and Time: Essays on Visions of History in Science Fiction and Fantasy, ed. David C. Wright Jr. and Allan W. Austin (Jefferson, NC: McFarland, 2010), 24.

23. Ibid.

24. Tomerlin, "Number Twelve," in Ramage, Forgotten Gems from "The Twilight Zone," 162.

25. This does not appear in the original version of the script.

26. Woiak, "Designing a Brave New World," 106.

27. In the original and shooting scripts, she "chose" Number 12, just like her mother.

28. In the original script, although she looks just like her mother, this line was eliminated. 
29. Tomerlin, "Number Twelve," in Ramage, Forgotten Gems from "The Twilight Zone," 161.

30. Ibid., 199.

31. Charles Beaumont, "The Beauti-

ful People," Worlds of If Science Fiction 4, no. 1 (1952): 12, http://www.gutenberg.org/ files/36258/36258h/36258h.htm.

32. In the shooting script, it reads, "teaching servants these days to use first names can be a problem." This was at some point changed to "you people" before shooting.

33. In the original teleplay, there is no maid, but it is Val that promised to call her by her first name, not mentioning anything related to class.

34. Beaumont, "The Beautiful People," 20.

35. Ibid., 21.

36. David Cooper, "The Ghost and Mrs. Muir": A Film Score Guide (Oxford: Scarecrow Press, 2005), 22.

37. Ibid.

38. For what has been written on the subject, see Karen Collins, "I'll Be Back: Recurrent Sonic Motifs in James Cameron's Terminator Films," in Music, Sound, and Science Fiction Cinema, ed. Philip Hayward (Eastleigh: John Libbey, 2004), $165-75$.

39. William Lawrence McGinney, "The Sounds of the Dystopian Future: Music for Science Fiction Films of the New Hollywood Era" (PhD diss., University of North Texas, 2009), 4.

40. Ibid., 58.

41. Ibid., 30.

42. Ibid., 59-6o.

43. Boris Kremenliev, "Background Music for Radio Drama," Hollywood Quarterly 4 (1949): 75-76.

44. "Radio Reviews: Columbia Workshop, Brave New World," Variety, February 1, 1956, 30.

45. "Sound Drama," Time, February 6, 1956.

46. Steven C. Smith, A Heart At Fire's Center: The Life and Music of Bernard Herrmann (Berkeley: University of California Press, 1991), 203.

47. For more on this, see Reba Wissner, $A D i$ mension of Sound: Music in "The Twilight Zone" (Hillsdale, NY: Pendragon Press, 2013), 1-17.

48. Christopher Palmer, The Composer in Hollywood (London: Marion Boyars, 1993), 245.

49. Royal S. Brown, "Herrmann, Hitchcock, and the Music of the Irrational," Cinema Journal 21 (1982): 23 .
50. Graham Bruce, Bernard Herrmann: Film Music and Narrative (Ann Arbor: UMI Research Press, 1985), 35.

51. William H. Rosar, "Bernard Herrmann: The Beethoven of Film Music?, Journal of Film Music 1 (2003): 138 .

52. Ibid., 131.

53. David Cooper, "Bernard Herrmann," in The New Grove Dictionary of Music and Musicians Online, ed. L. Macy, accessed February 4, 2013, http:// www.oxfordmusiconline.com.

54. Mark Russell and James Young, Film Music (East Sussex: Rotovision Books, 1998).

55. Kristopher Spencer, Film and Television Scores, 1950-1979: A Critical Survey By Genre (Jefferson, NC: McFarland, 2008), 229.

56. Kremenliev, "Background Music for Radio Drama," 76.

57. Karen Henson, "Interview with Fred Steiner," Archive of American Television, June 25, 2003, http://www.emmytvlegends.org.

58. This is specified in the American Federation of Musicians Television Film Labor Agreement dated June 5, 1959 and effective February 1, 1959, both in Paragraph 4, Subsection A and Paragraph 5, Subsection A. See also Wissner, Dimension of Sound, 2-3. This is indicated as the utilization of "live music exclusively on at least one out of each three filmed television programs" (Section 4A).

59. For more on the use of stock music, see Wissner, Dimension of Sound, 1-17.

6o. Martin Grams Jr., "The Twilight Zone": Unlocking the Door to a Television Classic (Lanham, MD: OTR, 2008), 70.

61. Personal correspondence with Robert Drasnin, letter dated May 30, 2013.

62. Wissner, Dimension of Sound, 87.

63. Jeff Bond, "Interview with Leonard Rosenman," in The Music of "Star Trek": Profiles in Style (Los Angeles: Lone Eagle Press, 1999), 128.

64. Buck Houghton, interview by Marc Scott Zicree, UFOTV Twilight Zone Audio Archive, $\mathrm{MP}_{3}$ recording.

65. Ron Rodman, Tuning In: American Narrative Television Music (Oxford: Oxford University Press, 2010), 33.

66. Ibid., 33.

67. Aside from "Number Twelve Looks Just Like You," multiple episodes from The Twilight Zone employ cues from the Brave New World radio play, 
often within otherworldly episodes that either feature futuristic technologies or portray utopian or dystopian societies: "I Shot An Arrow Into the Air" (January 15, 1960), "Mirror Image" (February 26, 1960), "Mr. Bevis" (June 3, 1960), “The Mighty Casey" (June 17, 1960), "A World of His Own" (July 1, 1960), "The Man in the Bottle" (October 7, 1960), "A Thing About Machines" (October 28, 1960), "A Penny For Your Thoughts" (February 3, 1961), "The Obsolete Man" (June 2, 1961), "It's a Good Life" (November 3, 1961), and "The Fugitive" (March 9, 1962).

68. McGinney, "Sounds of the Dystopian Future," 60.

69. Laurence E. MacDonald, The Invisible Art of Film Music: A Comprehensive History, 2nd ed.

(New York: Scarecrow Press, 2013), 227.

7o. Ibid., 27.

71. Quoted in Paul Cote, "De-Alienating the Alien: The Limits of Empathy in NBC's The Martian Chronicles Miniseries," in Orbiting Ray Bradbury's Mars: Biographical, Anthropological, Literary, Scientific, and Other Perspectives, ed. Gloria McMillan (Jefferson, NC: McFarland, 2013), 200.

72. For more on the score for "Eye of the Beholder," see Wissner, Dimension of Sound, 106-10.

73. William Wrobel, "Half-Diminished Seventh: The Bernard Herrmann Chord," Film Score Rundowns, accessed June 10, 2013, http://www.filmscorerundowns.net/herrmann/herrmannchord. pdf.

\section{REFERENCES}

American Federation of Musicians. "Television Film Labor Agreement." June 5, 1959.

Beaumont, Charles. "The Beautiful People." Worlds of If Science Fiction 4, no. 1 (1952): 4-17. http://www.gutenberg.org/ files $/ 36258 / 36258 \mathrm{~h} / 36258 \mathrm{~h}$.htm.

Bond, Jeff. "Interview with Leonard Rosenman." In The Music of Star Trek: Profiles in Style, 12731. Los Angeles: Lone Eagle Press, 1999.

Brown, Royal S. "Herrmann, Hitchcock, and the Music of the Irrational," Cinema Journal 21 (1982): 14-99.

Bruce, Graham Donald. Bernard Herrmann: Film Music and Narrative. Ann Arbor: UMI Research Press, 1985.

Collins, Karen. 'I'll Be Back: Recurrent Sonic Motifs in James Cameron's Terminator Films. In
Music, Sound, and Science Fiction Cinema, edited by Philip Hayward, 165-75. Eastleigh: John Libbey, 2004.

Cooper, David. "The Ghost and Mrs. Muir": A Film Score Guide. Oxford: Scarecrow Press, 2004.

_ . "Bernard Herrmann." The New Grove Dictionary of Music and Musicians Online, edited by L. Macy. Accessed February 4, 2013. http:// www.oxfordmusiconline.com.

Cote, Paul. "De-Alienating the Alien: The Limits of Empathy in NBC's The Martian Chronicles Miniseries," in Orbiting Ray Bradbury's Mars: Biographical, Anthropological, Literary, Scientific, and Other Perspectives, edited by Gloria McMillan, 193-210. Jefferson, NC: McFarland, 2013.

Drasnin, Robert. Personal Correspondence. Letter dated May 30, 2013.

Firchow, Peter. "Science and Conscience in Huxley's Brave New World." Contemporary Literature 16 (1975): 301-16.

Franklin, Morris Emory III. "Do Not Attempt to Adjust the Picture: The Cold War Crisis of Liberal Democracy and Science Fiction Television." $\mathrm{PhD}$ diss., University of Utah, 2008.

Grams, Martin Jr. "The Twilight Zone”: Unlocking the Door to a Television Classic. Lanham, MD: OTR, 2008.

Henson, Karen. "Interview with Fred Steiner." Archive of American Television, June 25, 2003. http://www.emmytvlegends.org.

Herrmann, Bernard. "Brave New World" Radio Score (1956). Autograph Manuscript, Box 150. CBS Collection, University of California, Los Angeles.

__. "Brave New World" Radio Score (1956). Copyist Manuscript, Box 14. CBS Collection, University of California, Los Angeles.

—_. "Eye of the Beholder" (1960). CBS Collection, University of California, Los Angeles.

Houghton, Buck. Interview by Marc Scott Zicree. UFOTV Twilight Zone Audio Archive. $\mathrm{MP}_{3}$ recording.

Huxley, Aldous. Brave New World. Cutchogue, NY: Buccaneer Books, 2006.

- Brave New World [radio play]. CBS Radio Workshop. Accessed March 3, 2011. http:// archive.org/details/CbsRadioWorkshop-BraveNewWorldjohnr2443 .

. Brave New World Revisited. New York: Harper and Brothers, 1958. 
Kremenliev, Boris. "Background Music for Radio Drama." Hollywood Quarterly 4 (1949): 75-83.

Lawrence, Novotny. "Reflections of a Nation's Angst; or, How I Learned to Stop Worrying and Love The Twilight Zone. In Space and Time: Essays on Visions of History in Science Fiction and Fantasy, edited by David C. Wright Jr. and Allan W. Austin, 9-28. Jefferson, NC: McFarland, 2010.

MacDonald, Laurence E. The Invisible Art of Film Music: A Comprehensive History. 2nd ed. New York: Scarecrow Press, 2013.

McGinney, William Lawrence. "The Sounds of the Dystopian Future: Music For Science Fiction Films of the New Hollywood Era." PhD diss., University of North Texas, 2009.

"Number Twelve Looks Just Like You." Cue Sheet. CBS Collection, University of California, Los Angeles.

Palmer, Christopher. The Composer in Hollywood. London: Marion Boyars, 1993.

Peller, Scott. "Laboring for a Brave New World: Our Ford and the Epsilons." In Huxley's "Brave New World": Essays, edited by David Garrett Izzo and Kim Kirkpatrick, 62-72. Jefferson, NC: McFarland, 2008.

Prosser, Harold Lee. Running From the Hunter: The Life and Works of Charles Beaumont. San Bernardino, CA: Borgo Press, 1996.

"Radio Reviews: Columbia Workshop, Brave New World." Variety, February 1, 1956, 30.

Ramage, Andrew, ed. Forgotten Gems from "The Twilight Zone." Vol. 2. Albany, GA: Bear Manor Media, 2006.

Rodman, Ron. Tuning In: American Narrative Television Music. Oxford: Oxford University Press, 2010.
Rosar, William H. "Bernard Herrmann: The Beethoven of Film Music?" Journal of Film Music 1 (2003): 121-50.

Russell, Mark, and James Young. Film Music. East Sussex: Rotovision Books, 1998.

Schmerl, Rudolf B. "Two Future Worlds of Aldous Huxley." PMLA 77 (1962): 328-34.

Smith, Steven C. A Heart At Fire's Center: The Life and Music of Bernard Herrmann. Berkeley: University of California Press, 1991.

"Sound Drama." Time, February 6, 1956.

Spencer, Kristopher. Film and Television Scores, 1950-1979: A Critical Survey By Genre. Jefferson, NC: McFarland, 2008.

Tomerlin, John. "Number Twelve Looks Just Like You." In Forgotten Gems of "The Twilight Zone", edited by Andrew Ramage. Vol. 2, 161-238. Albany, GA: Bear Manor Media, 2006.

Wierzbicki, James. "Music in The Twilight Zone." In Music in Science Fiction Television: Tuned to the Future, edited by K. J. Donnelly and Philip Hayward, 1-13. New York: Routledge, 2013.

Wissner, Reba. A Dimension of Sound: Music in "The Twilight Zone." Hillsdale, NY: Pendragon Press, 2013.

Witters, Sean. "Words Have to Mean Something More: Folkloric Reading in Brave New World." In Huxley's "Brave New World": Essays, edited by David Garrett Izzo and Kim Kirkpatrick, 62-72. Jefferson, NC: McFarland, 2008.

Woiak, Joanne. "Designing a Brave New World: Eugenics, Politics, and Fiction." Public Historian 29 (2007): 105-29.

Wrobel, William. "Half-Diminished Seventh: The Bernard Herrmann Chord.” Film Score Rundowns. Accessed June 10, 2013. http://www.filmscore rundowns.net/herrmann/herrmannchord.pdf. 